Article

\title{
Effects of Aquatic Macrophytes on Spatial Distribution and Feeding Habits of Exotic Fish Species Lepomis macrochirus and Micropterus salmoides in Shallow Reservoirs in South Korea
}

\author{
Jong-Yun Choi * ${ }^{-10}$ and Seong-Ki Kim \\ National Institute of Ecology, Seo-Cheon Gun 325-813, Chungcheongnam Province, Korea; skkim@nie.re.kr \\ * Correspondence: jyc311@naver.com; Tel.: +82-41-950-5473
}

Received: 16 January 2020; Accepted: 13 February 2020; Published: 15 February 2020

check for updates

\begin{abstract}
Aquatic macrophytes determine the physical complexity of aquatic environments and may influence the distribution and feeding habits of fish species. We explored the influence of different microhabitats, including vegetated beds (VB), edges of vegetated beds (EVB), and open water zones (OW), on two exotic fish species (Lepomis macrochirus and Micropterus salmoides) in shallow reservoirs. Lepomis macrochirus was more abundant in VB than in other zones and M. salmoides was mainly distributed in EVB. In VB, L. macrochirus mainly consumed branchiopods and isopods, while M. salmoides in EVB relied on relatively larger food items, such as dipterans, odonatans, and young fish. The consumption of young fish by M. salmoides, including L. macrochirus, showed little difference between winter and summer. Based on these findings, we suggest that young L. macrochirus $(\sim 20 \mathrm{~cm})$ utilize VB as a refuge to avoid predation by $M$. salmoides. Meanwhile, $M$. salmoides mainly occupied in areas surrounding VB, preying on animals at these edges. As such, the presence of aquatic macrophytes appears to plays a key role in the survival and population growth of L. macrochirus. Proper management of aquatic macrophytes can help reduce populations of exotic fish and support native fish species.
\end{abstract}

Keywords: habitat heterogeneity; piscivorous fish; prey size-selectivity; prey-predator interaction; freshwater refugia

\section{Introduction}

Habitat complexity directly affects food webs by altering predator-prey interactions due to changes in the physical environment [1-5]. Habitats with high structural heterogeneity provide refugia from predators and substrates suitable for spawning and foraging, supporting a greater diversity of animals [6,7]. Habitat heterogeneity in freshwater ecosystems is primarily determined by the physical structure and composition of macrophytes [8,9], with submerged macrophytes increasing physical complexity, providing suitable habitat for various animals [10,11]. Macrophytes' architecture has a significant bearing on food sources due to detritus tapping [12] and the growth of periphytic microalgae [13], supporting the formation of distinct animal communities [14-16], including both epiphytic and planktonic types, and diverse species composition. Habitat complexity controls energy transfer through food webs by direct and indirect influences on top-down and bottom-up pathways $[5,17]$ and may affect the strength of links between littoral and pelagic habitats, especially in small aquatic systems [6].

Freshwater macrophytes are effective in restricting the foraging activity of predators such as piscivorous fish [18,19], which are key determinants of ecosystem function [20]. Aquatic macrophytes are actively utilized as refugia for the survival and population growth of prey species such as 
zooplankton, invertebrates, and young fish. Young fish in particular use macrophytic refugia to avoid predation [21,22]. Increasing complexity provides increased opportunities for refuge, decreasing predator capture efficiency [23]. Furthermore, macrophytes support a high density of potential prey sources such as invertebrates, increasing their appeal as habitats for young fish [24-27]. In contrast, predatory fish are highly active in spaces where aquatic macrophytes are scarce or absent, and indiscriminate predation leads to a decrease in food sources and food scarcity, influencing predator population growth. This can result in decreased biodiversity. Larger fish are mainly observed in lakes or streams with fewer aquatic macrophytes [28], and the survival rate of young fish is lower in these areas compared to wetlands with a diverse array of macrophytes. As such, macrophytes can be regarded as essential habitat space for aquatic prey species (e.g., zooplankton, invertebrates, and young fish).

There are spatial limits to the area covered by macrophytes that can support prey individuals, and drift of prey animals can lead to insufficient space. Under these circumstances, prey animals may be detected by predators at the edge of vegetated beds. The growth and development of aquatic macrophytes is often seasonal, such that the spatial structure of a habitat may change over time. The development of various plant species creates habitats with complex structures. This habitat, in turn, supports diverse animals and provides an appropriate environment for successful survival and propagation $[29,30]$. However, when aquatic macrophytes provide relatively low cover and simple habitat structures, they are less able to support diverse aquatic animals. In simple habitat structures in cooler environments, predators generally have reduced food consumption [31], slow digestion rates [32], reduced swimming abilities [33], and limited mobility and activity [34]. Nonetheless, some fish species remain active in the winter, and their continued food consumption increases prey mortality and influences prey populations during the subsequent season.

Since their introduction in South Korea in the 1970s, the bluegill sunfish, Lepomis macrochirus, and the largemouth bass, Micropterus salmoides, have quickly spread through streams, reservoirs, and wetlands. As exotic species and top predators, they likely disturb ecosystems by preying on native fish, in the same way as Cichla kelberi in a reservoir located in the upper Paraná River in Brazil [35,36]. Pumpkinseed and largemouth bass are ecologically diverse and influenced by habitat complexity and, as such, are good models for testing the importance of habitat complexity and species interactions on ecosystem properties [37]. We aimed to elucidate the relative influence of aquatic macrophytes on the spatial distribution and feeding habits of L. macrochirus and M. salmoides. While the distribution and feeding habits of these species appear to be determined by local habitat structure and complexity, the importance of the relationship between seasonal succession and spatial distribution of fish and aquatic macrophytes has only recently been recognized. The pattern of macrophyte utilization by exotic fish species is still unclear, and their distribution is often underestimated. In shallow water ecosystems where macrophytes frequently dominate, these species are important in determining biodiversity [38]. We predicted that spatial distributions of the exotic fish species would differ according to macrophyte microhabitats and have a clear influence on the population growth of prey species. To test this objective, we surveyed 42 lentic ecosystems in South Korea, including physicochemical parameters of water, macrophytes, and fish assemblages. Based on the results, we explored the interactions between macrophytes and the fish community. To inform the removal and management of exotic fishes, as well as provide important data for identifying food webs within a freshwater ecosystem in order to infer its condition.

\section{Materials and Methods}

\subsection{Study Area}

South Korean freshwater ecosystems are temperate, with four distinct seasons, leading to a dynamic succession of biological communities. We selected reservoir sites located in southeastern South Korea near the mid- to lower parts of the Nakdong River. Historically, there have been numerous riverine 
reservoirs in the river basin, but much of this area has disappeared due to anthropogenic activities [39]. Agriculture is the dominant land use in the basin, and non-point source pollution continuously influences the reservoir ecosystems [40].

Currently, a total of 146 reservoirs are present in the Nakdong River basin [26]. All selected sites were dominated by L. macrochirus and M. salmoides, with low abundance or absence of other fish species. We explored the reservoirs for simultaneous presence of vegetated and open water zones. Forty-two reservoirs with both vegetated zones and open water zones were selected (Figure 1). Table S1 summarizes some of the main morphometries and limnological features of the reservoirs. Very shallow reservoirs with water surface area almost completely covered by macrophytes were excluded from this study.

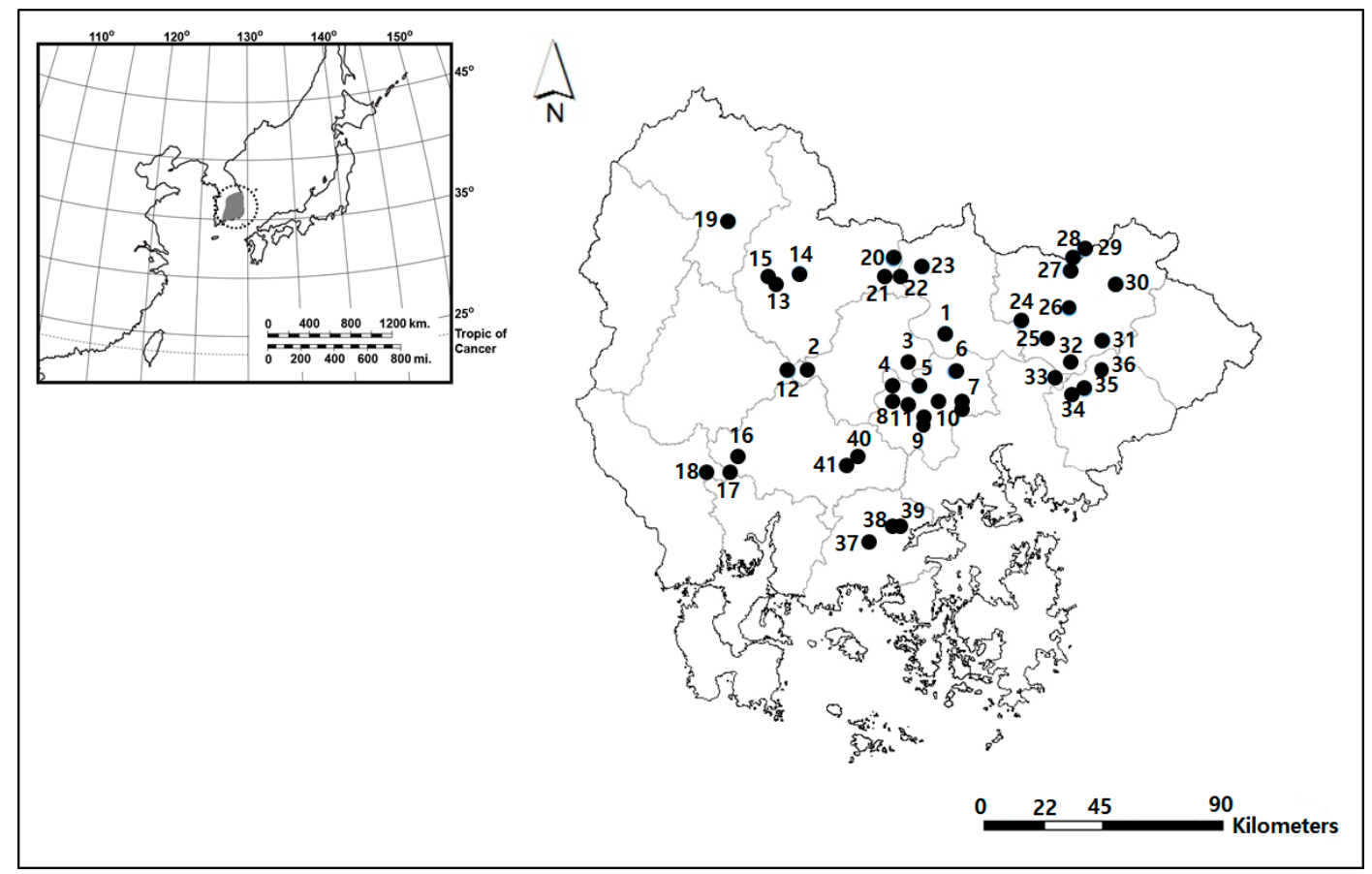

Figure 1. Map showing the 42 study sites located in southeastern South Korea. The study sites are shown as solid circles $(\bullet)$. The small map in the upper left corner indicates the Korean Peninsula.

Selected reservoirs were of a similar size (mean \pm SD: 155,845 $\pm 8516 \mathrm{~m}^{2}$ ), and most were utilized as agricultural water supply. The littoral zone of each reservoir was shallow with a deeper central area, resulting in clear separation of microhabitats with macrophytes being abundant only in the littoral zone. On this basis, we established three sampling zones including vegetated bed (VB), edge of vegetated bed (EVB), and open water (OW) zones. At the each of sampling zone, three replicates were established for monitoring. We then investigated environmental parameters and fish distribution in replicates of each zone.

\subsection{Monitoring Strategy}

We monitored the study sites in winter (December 2012) and summer (August 2013) to compare environmental parameters and fish distribution between seasons. Water depth, water temperature, dissolved oxygen concentration, conductivity, and $\mathrm{pH}$ were measured in the three zones at each reservoir. The EK-500 echo sounder was used to measure maximum water depth. We used a dissolved oxygen (DO) meter (model 58; YSI Inc., Yellow Springs, OH, USA) to determine water temperature and dissolved oxygen, and conductivity and $\mathrm{pH}$ were recorded using a conductivity meter (model 152; Fisher Scientific, Hampton, NH, USA) and an Orion 250A pH meter (Orion Research Inc., Boston, MA, USA) at $0.5 \mathrm{~m}$ depth. Water from $0.5 \mathrm{~m}$ depth to the surface was sampled using a $2 \mathrm{~L}$ 
column sampler. To determine chlorophyll $a$ concentration, water samples were filtered through $0.45 \mu \mathrm{m}$ mixed cellulose ester membrane filters (A045A047A; Advantech Co. Ltd., Taipei, Taiwan). The filtered membranes were carried out in cold $90 \%$ acetone, in darkness, at $20{ }^{\circ} \mathrm{C}$ for $4 \mathrm{~h}$. To improve extraction, the cells were disintegrated for $2 \mathrm{~min}$ in an ultrasonic bath. To remove cell debris and filter particles, the pigment extract was centrifuged at $5000 \mathrm{rpm}$ for 5-10 $\mathrm{min}$. The extinction was estimated at 600 and $750 \mathrm{~nm}$ with spectrophotometer (Japan Fantec Research Institute, Shizuoka, Japan) and using $1 \mathrm{~cm}$ glass cuvette [41]. The concentration of chlorophyll a was estimated by the formula: Chlorophyll $a=11.403 \cdot\left(\mathrm{A}_{600}-\mathrm{A}_{750}\right) \cdot \mathrm{V}_{\mathrm{a}} \cdot \mathrm{V}_{\mathrm{b}}{ }^{-1}$, derived on the basis of a factor. Designations at the formulas are: $\mathrm{V}_{\mathrm{a}}$-extract volume $(\mathrm{mL})$ and $\mathrm{V}_{\mathrm{b}}$-sample volume $(\mathrm{mL})$. Ten liters of water was filtered through a $68 \mu \mathrm{m}$ mesh plankton net at each sampling zone to collect invertebrates, which were preserved in 5\% formaldehyde. The collected invertebrates were classified as branchiopods, isopods, dipterans, and odonatans and counted using a stereozoom microscope at $200 \times$ magnification (Axioskop 40; Zeiss, Oberkochen, Germany).

Both L. macrochirus and M. salmoides were collected in the three zones of each reservoir. We collected fish using a gill net $(6 \times 6 \mathrm{~mm})$, cast net $(7 \times 7 \mathrm{~mm})$, and scoop net $(5 \times 5 \mathrm{~mm})$ along $300 \mathrm{~m}$ transects in each zone. At each sampling location, the gill net was set for $3 \mathrm{~h}$ after placement while the cast net and scoop net were used for $30 \mathrm{~min}$ and $2 \mathrm{~min}$, respectively. Collected fish were identified, counted, and measured for which length. The total number of fish captured at each sampling date was used to evaluate spatial changes in their abundance during the survey. Fish specimens were immediately fixed in a methanol-formaldehyde solution and kept for gut content analysis. We identified and counted all prey organisms, including branchiopods, isopods, dipterans, odonatans, and young fish in the gut contents of L. macrochirus and M. salmoides. The abundances of different prey items were calculated based on the number of each item in the gut relative to the total number of items. After fish collection, we measured width of per every $50 \mathrm{~m}$ of total $300 \mathrm{~m}$ transects in vegetated bed of each reservoir. The six widths of vegetated bed were averaged and utilized as the representative vegetated bed width of each reservoir.

\subsection{Data Analysis}

We used a two-way ANOVA to analyze statistical differences in the densities of L. macrochirus and M. salmoides, the effects of different habitat zones, and season. We also used a one-way ANOVA to analyze differences in environmental parameters and Invertebrate groups between each zone. The relationships between fish abundance and environmental parameters were tested using stepwise multiple regression in each of season. We confirmed the absence of error (Type I, Type II, etc.) and that the results were consistent regardless of the order that parameters were added.

We also utilized regression analysis to observe the relationship between L. macrochirus abundance and the area of VB in each reservoir. We tested linear, exponential, inverse, power, and logistic functions to determine the equation generating the best curve fit. Among the regression results, the curve-fitting equation that returned the highest determination coefficient was selected to explain the observed relationships. All statistical analyses were conducted using SPSS for Windows ver. 20 (IBM Corp. Released 2011. IBM SPSS Statistics for Windows, Version 20.0. Armonk, NY: IBM Corp.). Differences and relationships were considered significant at $p<0.05$.

\section{Results}

\subsection{Environmental Parameters and Invertebrate Distribution}

Vegetated bed width, depth, water temperature, dissolved oxygen, $\mathrm{pH}$, conductivity, and chlorophyll $a$ did not differ among reservoirs or seasons, but did differ among the three habitat type zones (Table 1). The greatest difference was observed in DO concentration among zones, where DO concentration was higher in OW than in VB or EVB. Particularly, the DO in winter was statistically different among zones (one-way ANOVA, $\mathrm{F}=2.81, \mathrm{P}<0.05$ ). In VB and $\mathrm{EVB}$, DO moderately increased 
during winter, but did not do so in OW. Depth was greatest in OW with little difference between the seasons. The width of vegetated beds was greater in summer, likely due to their seasonal growth and development. Other environmental factors differed few between zones.

Table 1. Environmental parameters and invertebrate groups in three zones of 42 reservoirs. VB: vegetated beds; EVB: edge of vegetated beds; OW: open water zones. VW, Vegetated bed width; WT, Water temperature; DO, Dissolved oxygen; Con., Conductivity; Chlorophyll a, Chl. A.

\begin{tabular}{ccccccc}
\hline \multirow{2}{*}{ Factors } & \multicolumn{3}{c}{ Winter } & \multicolumn{3}{c}{ Summer } \\
\cline { 2 - 7 } & VB & EVB & OW & VB & EVB & OW \\
\hline VW $(\mathrm{cm})$ & $50.9 \pm 26.9$ & - & - & $147.6 \pm 72.9$ & - & - \\
Depth $(\mathrm{m})$ & $0.6 \pm 0.4$ & $1.8 \pm 2.7$ & $3.7 \pm 4.8$ & $0.9 \pm 0.6$ & $2.2 \pm 1.9$ & $3.9 \pm 5.7$ \\
WT $\left({ }^{\circ} \mathrm{C}\right)$ & $2.7 \pm 1.7$ & $2.4 \pm 1.6$ & $2.4 \pm 2.1$ & $28.4 \pm 18.4$ & $27.4 \pm 15.6$ & $27.2 \pm 18.7$ \\
DO $(\%)$ & $71.6 \pm 23.7$ & $86.2 \pm 21.2$ & $91.7 \pm 26.8$ & $17.4 \pm 11.4$ & $45.2 \pm 20.7$ & $98.6 \pm 22.7$ \\
pH & $8.4 \pm 1.4$ & $7.2 \pm 0.9$ & $7.1 \pm 1.3$ & $6.7 \pm 2.7$ & $7.5 \pm 2.8$ & $7.6 \pm 1.7$ \\
Cond. $(\mu \mathrm{SS} / \mathrm{cm})$ & $227.8 \pm 137$ & $234.1 \pm 128$ & $232.7 \pm 134$ & $342.8 \pm 247$ & $357.7 \pm 285$ & $312.4 \pm 257$ \\
Chl. $a(\mu \mathrm{g} / \mathrm{L})$ & $5.7 \pm 6.3$ & $6.4 \pm 3.7$ & $5.6 \pm 4.5$ & $34.7 \pm 31.7$ & $36.4 \pm 27.1$ & $46.7 \pm 26.7$ \\
\hline Branchiopods $(\mathrm{ind} / \mathrm{L})$ & $0.7 \pm 6.4$ & - & - & $92.3 \pm 28.3$ & $32.1 \pm 17.1$ & $17.8 \pm 12.4$ \\
Isopods $(\mathrm{ind} / \mathrm{L})$ & $6.8 \pm 3.7$ & $2.4 \pm 6.9$ & - & $34.7 \pm 13.1$ & $24.7 \pm 10.4$ & $16.3 \pm 7.4$ \\
Dipterans $(\mathrm{ind} / \mathrm{L})$ & - & - & - & $12.4 \pm 6.8$ & $6.7 \pm 3.6$ & $3.3 \pm 2.7$ \\
Odonatans $(\mathrm{ind} / \mathrm{L})$ & $2.4 \pm 1.4$ & - & - & $17.4 \pm 7.2$ & $10.4 \pm 5.4$ & $2.5 \pm 2.7$ \\
\hline
\end{tabular}

Invertebrate groups (branchiopods, isopods, dipterans, and odonatans) were more abundant in VB and EVB than OW (Table 1). Branchiopod density was significantly higher in VB than in EVB or OW in both seasons (one-way ANOVA, $\mathrm{F}=2.81, p<0.05$ ).

\subsection{Distribution of Species among Different Zones}

Less than $5 \%$ of the fish collected were other species (than L. macrochirus and M. salmoides), and were thus negligible. The abundance and body size of L. macrochirus and M. salmoides differed among the three zones (Figure 2). Lepomis macrochirus was more abundant in VB than in other zones in both the summer and winter, although it became more abundant overall in winter (winter: $37 \pm 20.4$ ind./ $\mathrm{m}^{3}$; summer, $17 \pm 7.2$ ind. $/ \mathrm{m}^{3}$ ). We observed clear size differences in L. macrochirus between different zones. The smallest body sizes of L. macrochirus were found in VB. Interestingly, the body size of L. macrochirus was less than $20 \mathrm{~cm}$ in winter. However, individuals in EVB and OW had body sizes $>20 \mathrm{~cm}$, though fewer individuals were present. Meanwhile, few M. salmoides were found in VB, and they were mainly distributed in EVB. Their body sizes followed a pattern similar to L. macrochirus, whereby VB areas supported smaller individuals and the largest individuals were present in OW, followed by EVB. In EVB, M. salmoides individuals were relatively larger in winter than in summer, while in OW, their body size was similar across seasons. Finally, in OW, M. salmoides density was lower in winter than in summer. 


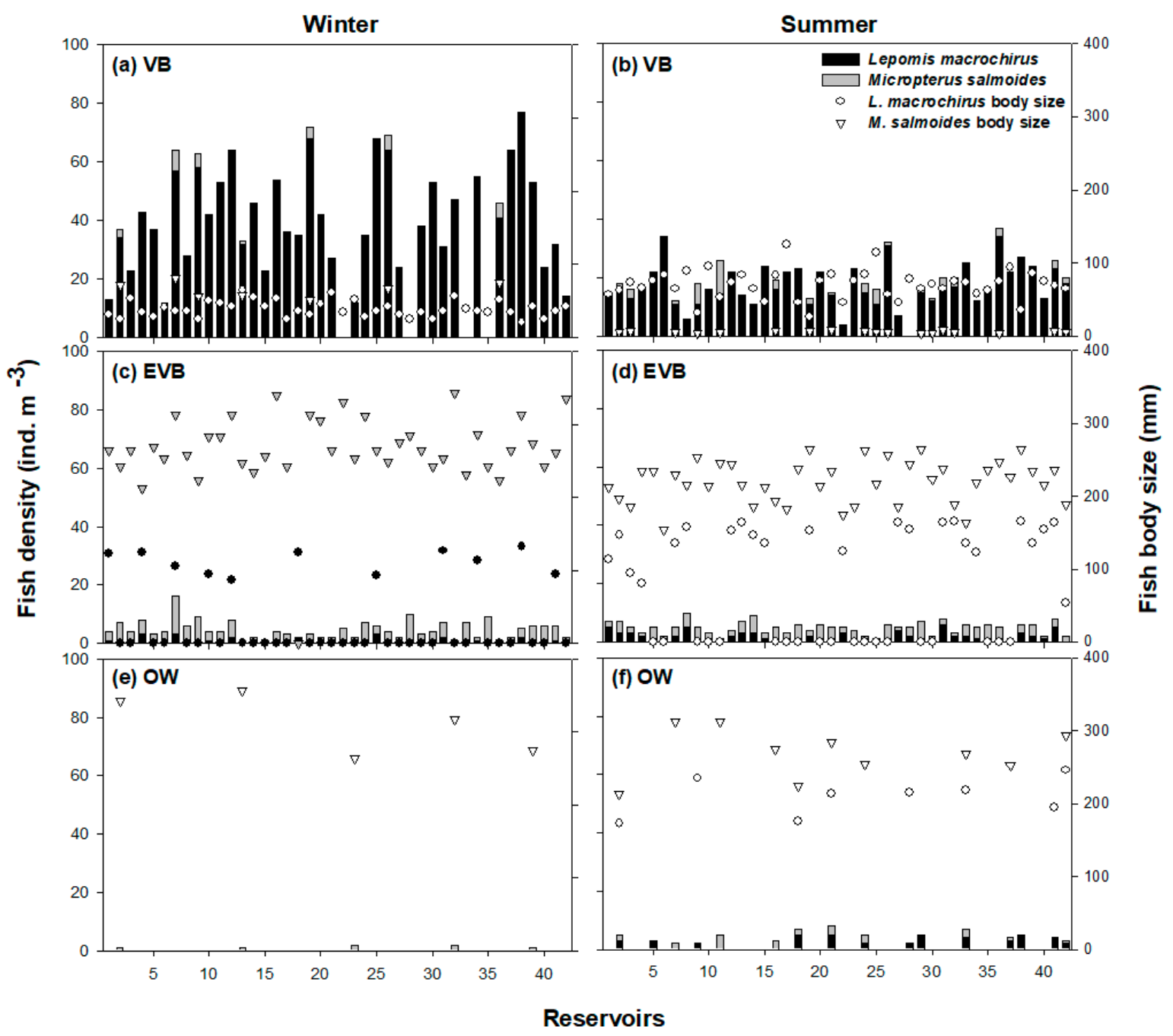

Figure 2. Density and body size of Lepomis macrochirus and Micropterus salmoides in three zones of 42 reservoirs. VB: vegetated beds; EVB: edge of vegetated beds; OW: open water zones. VB (a), EVB (c), and $\mathrm{OW}(\mathbf{e})$ in winter, and VB (b), EVB (d), and OW (f) in summer.

The results of the two-way ANOVA indicated that habitat and season affected both fish species (Table 2). Distribution of L. macrochirus was significantly influenced by both habitat and season, while $M$. salmoides was influenced only by microhabitat. Stepwise multiple regression examining the influence of habitat on the abundance of L. macrochirus in winter (Table 3) showed strong positive relationships with the biomass of aquatic macrophytes $(t=10.541, p=0.000)$ and dissolved oxygen. These observations could explain the presence of L. macrochirus predominantly in VB. However, the fishes were not related with environmental parameters in summer. The regression analysis between the abundance of L. macrochirus and VB area in winter indicated a positive relationship $\left(\mathrm{r}^{2}=0.67\right.$, $p<0.05$, Figure 3). In contrast, VB did not show any statistically significant correlation with abundance of L. macrochirus in summer and M. salmoides did not show any significant relationship with VB area in any season. $M$. salmoides density was only negatively related to $\mathrm{pH}$ (Table 3 ). 
Table 2. Two-way ANOVA results for the effects of habitat (vegetated beds, edge of vegetated bed, and open water zones) and season (winter and summer) on density of Lepomis macrochirus and Micropterus salmoides.

\begin{tabular}{cccccc}
\hline Fish & Component of Variance & df & Residual df & F & P \\
\hline \multirow{3}{*}{ Lepomis macrochirus } & Habitat & 2 & 246 & 233.32 & 0.00 \\
& Season & 1 & 246 & 3.56 & 0.03 \\
& Habitat x Season & 3 & 246 & 194.2 & 0.00 \\
\hline \multirow{3}{*}{ Micropterus salmoides } & Habitat & 2 & 246 & 87.43 & 0.02 \\
& Season & 1 & 246 & 0.77 & 0.91 \\
& Habitat $x$ Season & 3 & 246 & 8.24 & 0.63 \\
\hline
\end{tabular}

Table 3. Summary of stepwise multiple regression analysis to predict density of fish (response variable) with respect to environment parameters (explanatory variables) in winter. Data were transformed prior to analyses using either the arcsine-square root or log (all other variables) transformation.

\begin{tabular}{ccccc}
\hline Response Variable & Explanatory Variables & $\mathbf{B}_{\mathbf{j}}$ & $\mathbf{t}$ & $\boldsymbol{p}$-Value \\
\hline \multirow{2}{*}{ Lepomis macrochirus } & Macrophyte biomass $(\mathrm{g})$ & 0.018 & 10.541 & 0.000 \\
& Dissolved oxygen $(\%)$ & -0.141 & -2.342 & 0.037 \\
Micropterus salmoides & $\mathrm{pH}$ & -0.197 & -2.778 & 0.032 \\
\hline
\end{tabular}

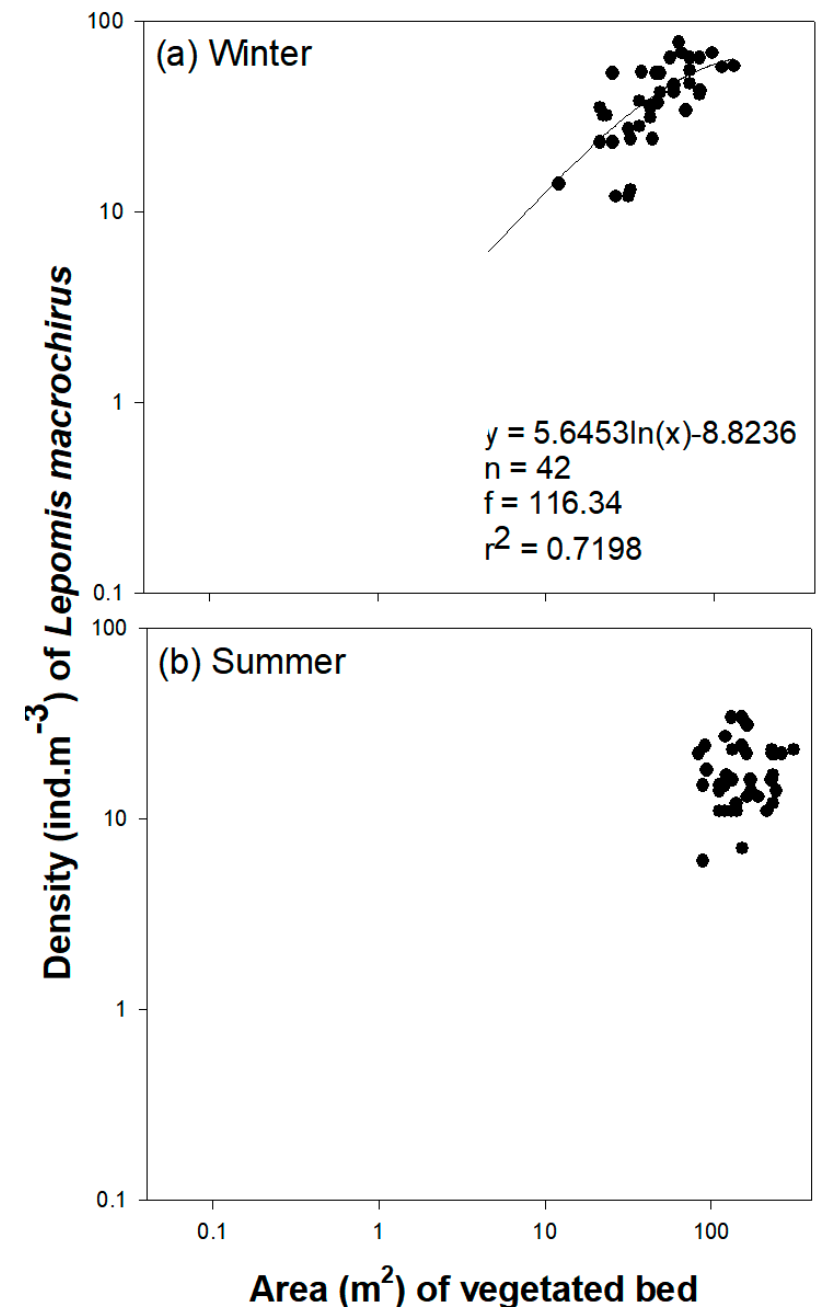

Figure 3. Relationship between Lepomis macrochirus density and vegetated bed width across 42 reservoirs in South Korea during winter (a) and summer (b). 


\subsection{Prey Consumption Patterns}

In summer, both species actively consumed prey in mainly VB and EVB (Table 4). The L. macrochirus diet differed between VB and EVB: branchiopods and isopods were utilized in VB, but only dipterans and odonatans were used in EVB. In contrast, L. macrochirus in OW consumed only isopods. In M. salmoides, greater prey consumption took place in EVB than in VB or OW, but there was no overall preference for specific prey items. In VB, M. salmoides preferentially selected food items with relatively small body size such as branchiopods, isopods, and dipterans. Meanwhile, its gut contents in OW included both odonatans and young fish. Young L. macrochirus were utilized as a food source for M. salmoides in OW and EVB, but not in VB. In VB, M. salmoides were of a similar size to L. macrochirus (in VB). The fishes were little consumed on prey items in winter, but interestingly, the consumption of young fish by M. salmoides showed little difference between winter and summer.

Table 4. Diet composition (ind. gut weight ${ }^{-1}$ ) of Lepomis macrochirus and Micropterus salmoides in winter and summer in three zones at 42 reservoirs. VB: vegetated beds; EVB: edge of vegetated beds; OW: open water zones. YOY fish: young of the year fish.

\begin{tabular}{|c|c|c|c|c|c|c|c|}
\hline \multirow{2}{*}{ Fish Species } & \multirow{2}{*}{ Diet Composition } & \multicolumn{3}{|c|}{ Winter } & \multicolumn{3}{|c|}{ Summer } \\
\hline & & VB & EVB & OW & VB & EVB & OW \\
\hline \multirow{5}{*}{ Lepomis macrochirus } & Branchiopods & - & - & - & $72.8 \pm 64.6$ & $35.4 \pm 47.3$ & - \\
\hline & Isopods & $8.4 \pm 12.4$ & - & - & $112.1 \pm 82$ & $51.4 \pm 32.1$ & $13.4 \pm 22.4$ \\
\hline & Dipterans & - & - & - & $26.5 \pm 32.1$ & $66.7 \pm 60.4$ & - \\
\hline & Odonatans & - & - & - & $13.5 \pm 22.7$ & $33.1 \pm 32.4$ & - \\
\hline & Young fishes & - & - & - & - & - & - \\
\hline \multirow{5}{*}{ Micropterus salmoides } & Branchiopods & - & - & - & $14.7 \pm 5.7$ & $2.0 \pm 0.6$ & - \\
\hline & Isopods & - & - & - & $26.4 \pm 66.4$ & $12.4 \pm 7.7$ & - \\
\hline & Dipterans & - & - & - & $32.4 \pm 75.1$ & $53.4 \pm 35.7$ & - \\
\hline & Odonatans & - & - & - & $12.5 \pm 44.1$ & $44.5 \pm 22.8$ & $11.4 \pm 16.7$ \\
\hline & Young fishes & - & $6.4 \pm 3.6$ & $4.6 \pm 4.1$ & - & $6.7 \pm 3.7$ & $9.4 \pm 13.5$ \\
\hline
\end{tabular}

\section{Discussion}

\subsection{Microhabitat Characteristics Influence Fish Distribution}

The abundance of L. macrochirus and M. salmoides clearly differed among the three microhabitats. VB supported a high abundance of fish, especially small L. macrochirus. In contrast, M. salmoides of $40-60 \mathrm{~cm}$ body size were mainly distributed in EVB. Since aquatic macrophytes provide appropriate habitat for animals such as invertebrates and young fish and refugia from larger fish predators $[16,18,42,43]$, most animals utilizing macrophyte habitats have smaller body size and concentrate themselves in VB when predators are present in high abundance [42].

Micropterus salmoides is known as a strong predator, which creates disturbance in ecosystems as they indiscriminately prey on eggs of other fish species, young fish, and invertebrates [44]. We observed that $M$. salmoides consumed various prey and, in particular, utilized young fish as a food source. In spite of this, M. salmoides did not linger in VB zones. Savino and Stein [45] suggested that it actively forages in areas of moderate or sub-moderate aquatic macrophyte cover. Since most of South Korea's reservoirs have been constructed to secure agricultural water, the bulk of the surrounding land is agricultural or residential, resulting in a high influx of total nitrate and phosphorus, which induces excessive growth of aquatic macrophytes. For this reason, most of the reservoirs' littoral areas show high coverage of emergent macrophytes such as Phragmites communis and/or Paspalum distichum, which is unsuitable habitat for fish such as M. salmoides. Accordingly, we found that M. salmoides abundance was relatively lower in reservoirs with high coverage of aquatic macrophytes. M. salmoides did not frequent VB habitat, and instead consumed prey items in EVB areas. We often found young individuals $(<20 \mathrm{~cm})$ of L. macrochirus in the gut content of M. salmoides collected from EVB, suggesting that M. salmoides could consume L. macrochirus individuals of the size found in VB. In contrast, L. macrochirus has a rhomboid body form advantageous in swimming among the stems and leaves of aquatic macrophytes. In addition, $L$. macrochirus predation is influenced less by the abundance of aquatic macrophytes due to 
its mode of feeding (they suck in food with water). Previous studies have suggested that L. macrochirus can feed effectively in the complex habitat space created by aquatic macrophytes [46]. For M. salmoides, however, the abundance of aquatic macrophytes is a significant limiting factor in its foraging activities. Moreover, the structural complexity of VB supports a high density of prey items such as invertebrates, which utilize it as a refuge from predation $[25,47]$. Therefore, aquatic macrophytes can be interpreted as important in maintaining the coexistence of L. macrochirus and M. salmoides, enabling them to partition their space. As the littoral zones of South Korean reservoirs are suitable for development of aquatic macrophytes, they can support population growth of L. macrochirus and M. salmoides.

Most of the environmental variables examined did not show significant differences among the three microhabitats, reflecting very little physicochemical variation. This indicates that the distribution patterns of L. macrochirus and M. salmoides were primarily influenced by habitat structure and prey-predator interactions. As the exception, clear differences in DO during summer were the result of restricted oxygen exchange with the atmosphere under high summertime macrophyte coverage in VB areas [48]. We did not deal with the environmental variables of the bottom layer because it is rich in organic matter, which does not reflect the physicochemical characteristics of water. The bottom layer reflects higher conductivity and lower dissolved oxygen concentrations than the surface or middle layer. In addition, L. macrochirus and M. salmoides do not distribute well at the bottom layer. They avoid dark bottom layer because their foraging activity use sight. Although the bottom layer may exhibit different characteristics from other layers, it is not important to understand the distribution of L. macrochirus and M. salmoides.

Among invertebrate groups, branchiopods and isopods were more abundant in VB than EVB or OW. Some studies have suggested that submerged parts of macrophytes are utilized as both substrate for epibiotic species as well as refugia from predation $[3,26]$. The various plant species create complex spatial structures, decreasing the foraging efficiency of visual predators such as fish. Therefore, the presence of VB can support the survival and population growth of various prey such as invertebrates. As an exception, L. macrochirus did feed in VB, and was sometimes present at high densities in this zone. It is possible that VB areas with a high abundance of L. macrochirus were not suitable refugia for invertebrates [23]. However, we found that L. macrochirus consumed various invertebrate species, including branchiopods such as Daphnia and Simocephalus spp. and isopods such as Cyclops and Mesocyclops spp. These pelagic species are preferred by consumers because they are easily pursued and captured by fish predators [49]. However, species such as Alona and Chydorus spp., which attach to the stems and leaves of macrophytes, are not as easily consumed by fish [50]. When easy-to-exploit resources such as planktonic species are exhausted, epiphytic species can be used as alternative food sources for secondary consumers [51]. Thus, research on epiphytic species is needed to understand biodiversity and food webs in freshwater ecosystems.

\subsection{Role of Winter Macrophytes for Lepomis macrochirus}

The feeding habits of L. macrochirus and M. salmoides differed between winter and summer, with more varied prey captured in summer. Interestingly, consumption of young fish by M. salmoides was similar in winter and summer, with an average capture rate of an average of 6.7 fish during the summer within EVB and an average of 6.4 fish in winter, indicating no significant influence of water temperature. Fish predation was generally higher during warm periods and lower in winter. In general, all foraging related capacities, as well as other vital rates in ectotherms including fish, are strongly dependent on water temperature, in turn imposing strong constraints on energy acquisition, physiological adaptations, and behavior [52]. Access to resources becomes so limiting that starvation is initiated. Larger individuals can survive for longer than smaller individuals because of their higher ratio of energy reserves to metabolic rate. Likewise, invertebrates such as Daphnia show depressed feeding activity in winter, with consequent slow growth rates [53]. Life cycles, lifespan, offspring number, and tolerance are also determined by temperature [54]. When food consumption decreases, individuals minimize their energy expenditure by reducing movement. In EVB, however, M. salmoides 
foraging posed a consistent threat to L. macrochirus regardless of season, leading to L. macrochirus moving into VB zones. However, although aquatic macrophytes can provide physical refuge for L. macrochirus, seasonal growth patterns of aquatic macrophytes lead to changes in habitat complexity and structure. Therefore, L. macrochirus utilizes growing and developing aquatic macrophytes during spring and fall, while winter withering leads to a reduction in its habitat space. However, winter does not cause a total eradication of aquatic macrophytes. While free-floating hydrophytes such as Spirodela polyrhiza L. and Salvinia natans L. and submerged hydrophytes such as Ceratophyllum demersum L., Potamogeton crispus L., and Vallisneria natans (Lour.) H. Hara mostly wither and die back to the benthos during winter, the leaves and stems of emergent hydrophytes such as Phragmites communis Trin., Zizania latifolia (Griseb.) Turcz., and Paspalum distichum var. indutum Shinners maintain a similar morphology during summer and winter. The emergent hydrophytes that maintain their shape during winter function as highly important refugia for L. macrochirus to avoid predation by M. salmoides. However, these winter habitats provide a very small area of refuge compared to their summer area. Furthermore, emergent hydrophytes typically develop at a depth of 1-2 $\mathrm{m}$. Therefore, the habitable area of each reservoir differs, presenting varying refuge effectiveness for L. macrochirus. Predictably, L. macrochirus density increased as VB area increased. Since only L. macrochirus able to secure the remaining $\mathrm{VB}$ as a refuge during winter can survive predation by $M$. salmoides, a seasonal decrease in the L. macrochirus population is likely to take place. These factors likely contribute to the persistent coexistence of $M$. salmoides predators and L. macrochirus prey within a limited habitat space.

L. macrochirus that do secure refuge in VB during winter become important primary individuals for population growth the following year. In addition, reservoirs with a wide VB area during winter support a greater density of L. macrochirus individuals to reproduce the following summer. In contrast, reservoirs with a smaller VB area during winter will require more time for the population size to reach pre-summer levels, even if a wide VB area is secured in the following year. In cases where a large area of VB is available during the summer but is absent in the winter, or when only a very small area can be utilized, a considerable number of L. macrochirus are likely to be captured by M. salmoides, contributing to population growth of the latter species. Consequently, the area of VB during winter is an important factor in determining the next generation of L. macrochirus, and likely influences its continued survival and growth.

\subsection{Absence of Predation on L. macrochirus and M. salmoides}

The absence of predators also likely contributes to the spread of L. macrochirus and M. salmoides. Channa argus (Perciformes: Channidae) is at the top of the food chain in South Korea's freshwater ecosystems, and while it does consume fish such as L. macrochirus and M. salmoides [55], its population is in decline and does not provide a strong top-down influence. Channa argus is native to South Korea and is regularly captured for use in traditional medicine. Its fishery is most intensive during May and June, within the range of 80 to 100 fishing activity every year. This fishing season takes place when their preferred VB habitat has lower cover and coincides with spawning [56], making this fishery a significant factor in its decline. Channa argus is fished intensively in southern provinces (especially Gyeongsangnam-do and Gyeongsangbuk-do), with decreasing annual catches; moreover, C. argus was observed at only three sites in this study. Its absence as an apex predator increases the population size and dominance of L. macrochirus and M. salmoides and decreases the overall health of the ecosystem [57]. As a result, L. macrochirus and M. salmoides are now the most frequently observed species in most South Korean freshwater ecosystems.

\subsection{Strategy for Managing Exotic Fish Species}

Our study sites supported a high abundance of L. macrochirus and M. salmoides, and the density of other species was considerably lower. In spite of the fact that L. macrochirus constituted more than $70 \%$ of the fish biomass at some sites, which was higher than that of M. salmoides, policies and planning for its management by the government and civic groups have not been as extensive. This may be 
because these groups place comparatively low importance on shallow wetlands and reservoirs with minimal current and abundant macrophytes, such as those preferred by L. macrochirus. These areas have historically been perceived as low in value, and have been developed for farmland, embankment construction, and health control, leading to degradation or extinction of many wetlands. There is increasing awareness of their importance to biodiversity and landscape value, and conservation efforts have been implemented, but these ecosystems are often subject to disturbance for use as water resources.

Meanwhile, M. salmoides dominate in deeper water bodies with lower macrophyte cover (i.e., OW). Construction and refortification for securing water, drought and flood prevention, and power generation are carried out at such areas, and their ecosystem services are better recognized. As such, management by removal of exotic fish species such as M. salmoides is carried out consistently. Furthermore, research and media coverage of issues such as predator-prey interactions, influence on the ecosystem, and environmental risk tend to focus on M. salmoides. As a result, L. macrochirus is widely distributed across South Korea [58], representing a persistent threat to native fish species and their habitats. Nine wetlands in South Korea, including the Upo wetland, belong to the Ramsar Convention on Wetlands and receive protection and management. However, reports indicate a significantly higher relative richness of exotic fish species such as L. macrochirus within these wetlands [59]. Therefore, while the removal and management of M. salmoides in areas such as dam reservoirs and deep lakes is taking place, there is an urgent need for management of L. macrochirus in shallow wetlands or reservoirs to guard against the decrease and extinction of native fish species.

Our findings indicate that the abundance of aquatic macrophytes in each reservoir influences the density of L. macrochirus. As agricultural and/or residential areas surround most wetlands, runoff of nutrients such as nitrate and phosphorus can increase the growth of aquatic macrophytes. Controlling these factors by reducing or purifying runoff could help reduce macrophyte cover and remove L. macrochirus. Management of M. salmoides by means other than physical removal is more difficult due to their high density, active foraging, and high fertility rates. Nutrient loading control can reduce the abundance of aquatic macrophytes, and consequently reduce the acceleration of the interaction (i.e., foraging of young L. macrochirus to M. salmoides) between L. macrochirus and M. salmoides. It can be increased the populations and density of native fish species and contribute to securing biodiversity.

Supplementary Materials: The following are available online at http://www.mdpi.com/2071-1050/12/4/1447/s1, Table S1: Morphometries and limnological description of 42 reservoirs. Fluctuation is the annual water level fluctuation (values $>1 \mathrm{~m}$ are regulated). Rainfall/ground, Rainfall and ground water.

Author Contributions: Conceptualization, J.-Y.C.; methodology, S.-K.K.; validation, J.-Y.C. and S.-K.K.; investigation, J.-Y.C. and S.-K.K.; resources, J.-Y.C.; data curation, J.-Y.C.; writing-original draft preparation, J.-Y.C. and S.-K.K.; writing-review and editing, J.-Y.C.; visualization, J.-Y.C.; supervision, J.-Y.C.; project administration, J.-Y.C.; funding acquisition, S.-K.K. All authors have read and agreed to the published version of the manuscript.

Funding: This research was supported by the Basic Science Research Program through the National Research Foundation of Korea (NRF) funded by the Ministry of Education (grant number: NRF-2012-R1A6A3A04040793).

Conflicts of Interest: The authors declare no conflict of interest.

\section{References}

1. Bazzaz, F.A. Plant species diversity in old-field successional ecosystems in southern Illinois. Ecology 1975, 56, 485-488. [CrossRef]

2. Chick, J.H.; McIvor, C.C. Patterns in the abundance and composition of fishes among beds of different macrophytes: Viewing a littoral zone as a landscape. Can. J. Fish. Aquat. Sci. 1994, 51, 2873-2882. [CrossRef]

3. Manatunge, J.; Asaeda, T.; Priyadarshana, T. The influence of structural complexity on fish-zooplankton interactions: A study using artificial submerged macrophytes. Environ. Biol. Fishes 2000, 58, 425-438. [CrossRef]

4. Ruetz, C.R.; Breen, M.J.; Vanhaitsma, D.L. Habitat structure and fish predation: Effects on invertebrate colonization and breakdown of stream leaf packs. Freshw. Biol. 2006, 51, 797-806. [CrossRef]

5. Genkai-Kato, M. Macrophyte refuges, prey behaviour and trophic interactions: Consequences for lake water clarity. Ecol. Lett. 2007, 10, 105-114. [CrossRef] [PubMed] 
6. Declerck, S.; Vandekerkhove, J.; Johansson, L.; Muylaert, K.; Conde-Porcuna, J.M.; Van der Gucht, K.; Pérez-Martínez, C.; Lauridsen, T.; Schwenk, K.; Zwart, G.; et al. Multi-group biodiversity in shallow lakes along gradients of phosphorus and water plant cover. Ecology 2005, 86, 1905-1915. [CrossRef]

7. Vieira, L.C.G.; Bini, L.M.; Velho, L.F.M.; Mazão, G.R. Influence of spatial complexity on the density and diversity of periphytic rotifers, microcrustaceans and testate amoebae. Fundam. Appl. Limnol. 2007, 170, 77-85. [CrossRef]

8. Meerhoff, M.; Mazzeo, N.; Moss, B.; Rodríguez-Gallego, L. The structuring role of free-floating versus submerged plants in a subtropical shallow lake. Aquat. Ecol. 2003, 37, 377-391. [CrossRef]

9. Choi, J.Y.; Jeong, K.S.; La, G.H.; Kim, S.K.; Joo, G.J. Sustainment of epiphytic microinvertebrate assemblage in relation with different aquatic plant microhabitats in freshwater wetlands (South Korea). J. Limnol. 2014, 73, 11-16. [CrossRef]

10. Jeppesen, E.; Lauridsen, T.L.; Kairesalo, T.; Perrow, M.R. Impact of submerged macrophytes on fish-zooplankton interactions in lakes. In The Structuring Role of Submerged Macrophytes in Lakes; Springer Verlag: New York, NY, USA, 1998; pp. 91-114.

11. Blindow, I.; Hargeby, A.; Bálint, M.A.; Andersson, G. How important is the crustacean plankton for the maintenance of water clarity in shallow lakes with abundant submerged vegetation? Freshw. Biol. 2000, 44, 185-197. [CrossRef]

12. Rooke, J.B. The invertebrate fauna of four macrophytes in a lotic system. Freshw. Biol. 1984, 14, 507-513. [CrossRef]

13. Dudley, T.L. The role of plant complexity and epiphyton in colonization of macrophytes by stream insects. Int. Vereinigung Theoretische Angewandte Limnol. 1988, 23, 1153-1158. [CrossRef]

14. Sand-Jensen, K.; Søndergaard, M. Phytoplankton and epiphyte development and their shading effect on submerged macrophytes in lakes of different nutrient status. Int. Rev. Gesamten Hydrobiol. Hydrogr. 1981, 66, 529-552. [CrossRef]

15. Van Donk, E.; van de Bund, W.J. Impact of submerged macrophytes including charophytes on phyto- and zooplankton communities: Allelopathy versus other mechanisms. Aquat. Bot. 2002, 72, 261-274. [CrossRef]

16. Warfe, D.M.; Barmuta, L.A. Habitat structural complexity mediates food web dynamics in a freshwater macrophyte community. Oecologia 2006, 150, 141-154. [CrossRef] [PubMed]

17. Johnson, M.P.; Frost, N.J.; Mosley, M.W.; Roberts, M.F.; Hawkins, S.J. The area-independent effects of habitat complexity on biodiversity vary between regions. Ecol. Lett. 2003, 6, 126-132. [CrossRef]

18. Lauridsen, T.L.; Lodge, D.M. Avoidance by Daphnia magna of fish and macrophytes: Chemical cues and predator-mediated use of macrophyte habitat. Limnol. Oceanogr. 1996, 41, 794-798. [CrossRef]

19. Moss, B.; Kornijow, R.; Measey, G. The effect of nymphaeid (Nuphar lutea) density and predation by perch (Perca fluviatilis) on the zooplankton communities in a shallow lake. Freshw. Biol. 1998, 39, 689-697. [CrossRef]

20. Hooper, D.U.; Chapin, F.S.; Ewel, J.J.; Hector, A.; Inchausti, P.; Lavorel, S.; Lawton, J.H.; Lodge, D.M.; Loreau, M.; Naeem, S.; et al. Effects of biodiversity on ecosystem functioning: A consensus of current knowledge. Ecol. Monogr. 2005, 75, 3-35. [CrossRef]

21. Okun, N.; Mehner, T. Distribution and feeding of juvenile fish on invertebrates in littoral reed (Phragmites) stands. Ecol. Freshw. Fish 2005, 14, 139-149. [CrossRef]

22. Lehtiniemi, M. Swim or hide: Predator cues cause species specific reactions in young fish larvae. J. Fish Biol. 2005, 66, 1285-1299. [CrossRef]

23. Crowder, L.B.; Cooper, W.E. Habitat structural complexity and the interaction between bluegills and their prey. Ecology 1982, 63, 1802-1813. [CrossRef]

24. Cheruvelil, K.S.; Soranno, P.A.; Madsen, J.D.; Roberson, M.J. Plant architecture and epiphytic macroinvertebrate communities: The role of an exotic dissected macrophyte. J. N. Am. Benthol. Soc. 2002, 21, 261-277. [CrossRef]

25. Meerhoff, M.; Fosalba, C.; Bruzzone, C.; Mazzeo, N.; Noordoven, W.; Jeppesen, E. An experimental study of habitat choice by Daphnia: Plants signal danger more than refuge in subtropical lakes. Freshw. Biol. 2006, 51, 1320-1330. [CrossRef]

26. Choi, J.Y.; Jeong, K.S.; Kim, S.K.; La, G.H.; Chang, K.H.; Joo, G.J. Role of macrophytes as microhabitats for zooplankton community in lentic freshwater ecosystems of South Korea. Ecol. Inform. 2014, 24, 177-185. [CrossRef] 
27. Choi, J.Y.; Jeong, K.S.; La, G.H.; Chang, K.H.; Joo, G.J. The influence of aquatic macrophytes on distribution and feeding habit of two Asplanchna species (A. priodonta and A. herrickii) in shallow wetlands, South Korea. J. Limnol. 2015, 74, 1-11. [CrossRef]

28. Davey, A.J.H.; Hawkins, S.J.; Turner, G.F.; Doncaster, C.P. Size-dependent microhabitat use and intraspecific competition in Cottus gobio. J. Fish Biol. 2005, 67, 428-443. [CrossRef]

29. Thomaz, S.M.; Dibble, E.D.; Evangelista, L.R.; Higuti, J.; Bini, L.M. Influence of aquatic macrophyte habitat complexity on invertebrate abundance and richness in tropical lagoons. Freshw. Biol. 2008, 53, 358-367. [CrossRef]

30. Kuczynska-Kippen, N.; Nagengast, B. The influence of the spatial structure of hydromacrophytes and differentiating habitat on the structure of rotifer and cladoceran communities. Hydrobiologia 2006, 559, 203-212. [CrossRef]

31. Hathaway, E.S. The relation of temperature to the quantity of food consumed by fishes. Ecology 1927, 8, 428-434. [CrossRef]

32. Araya, H.; Contreras, P.; Alvina, M.; Vera, G.; Pak, N. A comparison between an in vitro method to determine carbohydrate digestion rate and the glycemic response in young men. Eur. J. Clin. Nutr. 2002, 56, 735. [CrossRef] [PubMed]

33. Beamish, F.W.H. Swimming capacity. Fish Physiol. 1978, 7, 101-187.

34. Cooke, S.J.; Grant, E.C.; Schreer, J.F.; Philipp, D.P.; Devries, A.L. Low temperature cardiac response to exhaustive exercise in fish with different levels of winter quiescence. Comp. Biochem. Physiol. Part A Mol. Integr. Physiol. 2003, 134, 157-165. [CrossRef]

35. Pelicice, F.M.; Agostinho, A.A. Fish fauna destruction after the introduction of a non-native predator (Cichla kelberi) in a Neotropical reservoir. Biol. Invasions 2009, 11, 1789-1801. [CrossRef]

36. Pelicice, F.M.; Latini, J.D.; Agostinho, A.A. Fish fauna disassembly after the introduction of a voracious predator: Main drivers and the role of the invader's demography. Hydrobiologia 2015, 746, 271-283. [CrossRef]

37. Mittelbach, G.G. Foraging efficiency and body size: A study of optimal diet and habitat use by bluegills. Ecology 1981, 62, 1370-1386. [CrossRef]

38. Michelan, T.S.; Thomaz, S.M.; Mormul, R.P.; Carvalho, P. Effects of an exotic invasive macrophyte (tropical signalgrass) on native plant community composition, species richness and functional diversity. Freshw. Biol. 2010, 55, 1315-1326. [CrossRef]

39. Burkett, V.; Kusler, J. Climate change: Potential impacts and interactions in wetlands of the United States. J. Am. Water Resour. Assoc. 2000, 36, 313-320. [CrossRef]

40. Peterjohn, W.T.; Correll, D.L. Nutrient dynamics in an agricultural watershed: Observations on the role of a riparian forest. Ecology 1984, 65, 1466-1475. [CrossRef]

41. Wetzel, R.G.; Likens, G.E. Limnological Analyses; Springer-Verlag: New York, NY, USA, 2000.

42. Stansfield, J.H.; Perrow, M.R.; Tench, L.D.; Jowitt, A.J.; Taylor, A.A. Submerged macrophytes as refuges for grazing Cladocera against fish predation: Observations on seasonal changes in relation to macrophyte cover and predation pressure. In Shallow Lakes' 95; Springer: Dordrecht, The Netherlands, 1997; pp. 229-240.

43. Grenouillet, G.; Pont, D. Juvenile fishes in macrophyte beds: Influence of food resources, habitat structure and body size. J. Fish Biol. 2001, 59, 939-959. [CrossRef]

44. Hambright, K.D. Experimental analysis of prey selection by largemouth bass: Role of predator mouth width and prey body depth. Trans. Am. Fish. Soc. 1991, 120, 500-508. [CrossRef]

45. Savino, J.F.; Stein, R.A. Behavior of fish predators and their prey: Habitat choice between open water and dense vegetation. Environ. Biol. Fishes 1989, 24, 287-293. [CrossRef]

46. Engel, S. The impact of submerged macrophytes on largemouth bass and bluegills. Lake Reserv. Manag. 1987, 3, 227-234. [CrossRef]

47. Choi, J.Y.; Jeong, K.S.; Kim, S.K.; Joo, G.J. Impact of habitat heterogeneity on the biodiversity and density of the zooplankton community in shallow wetlands (Upo wetlands, South Korea). Oceanol. Hydrobiol. Stud. 2016, 44, 485-492. [CrossRef]

48. Miranda, L.E.; Hodges, K.B. Role of aquatic vegetation coverage on hypoxia and sunfish abundance in bays of a eutrophic reservoir. Hydrobiologia 2000, 427, 51-57. [CrossRef]

49. Perrow, M.R.; Jowitt, A.J.D.; Stansfield, J.H.; Phillips, G.L. The practical importance of the interactions between fish, zooplankton and macrophytes in shallow lake restoration. Hydrobiologia 1999, 395, 199-210. [CrossRef] 
50. Castro, B.B.; Goncalves, F. Planktivory in non-indigenous fish and implications for trophic interactions in a Mediterranean shallow lake. Ann. Limnol. Int. J. Limnol. 2011, 47, 269-280. [CrossRef]

51. Nicolle, A.; Hansson, L.A.; Bronmark, C. Habitat structure and juvenile fish ontogeny shape zooplankton spring dynamics. Hydrobiologia 2010, 652, 119-125. [CrossRef]

52. Garvey, J.E.; Ostrand, K.G.; Wahl, D.H. Energetics, predation, and ration affect size-dependent growth and mortality of fish during winter. Ecology 2004, 85, 2860-2871. [CrossRef]

53. Rellstab, C.; Spaak, P. Lake origin determines Daphnia population growth under winter conditions. J. Plankton Res. 2008, 31, 261-271. [CrossRef]

54. Orcutt, J.D.; Porter, K.G. The synergistic effects of temperature and food concentration of life history parameters of Daphnia. Oecologia 1984, 63, 300-306. [CrossRef] [PubMed]

55. Odenkirk, J.; Owens, S. Expansion of a Northern Snakehead population in the Potomac River System. Trans. Am. Fish. Soc. 2007, 136, 1633-1639. [CrossRef]

56. Cudmore, B.; Mandrak, N.E.; Department of Fisheries and Oceans, Ottawa, ON(Canada); Canadian Science Advisory Secretariat, Ottawa, ON(Canada). Risk Assessment for Northern Snakehead (Channa Argus) in Canada; Fisheries and Oceans Canada, Science: Calgary, AB, Canada, 2006.

57. Connell, J.H. A predator-prey system in the marine intertidal region. I. Balanus glandula and several predatory species of Thais. Ecol. Monogr. 1970, 40, 49-78.

58. Lau, H.H.; Huang, J.; Kwan, Y.S.; Lee, W.O.; Won, Y.J. Genetic distribution pattern of bluegill sunfish Lepomis macrochirus in freshwater ecosystems across Korea. Anim. Syst. Evol. Divers. 2009, 25, 325-329. [CrossRef]

59. Jo, H.; Jang, M.H.; Jeong, K.S.; Joo, G.J.; Yoon, J.D. Long-term changes in fish community and the impact of exotic fish, between the Nakdong River and Upo Wetlands. J. Ecol. Environ. 2011, 34, 59-68. [CrossRef]

(C) 2020 by the authors. Licensee MDPI, Basel, Switzerland. This article is an open access article distributed under the terms and conditions of the Creative Commons Attribution (CC BY) license (http://creativecommons.org/licenses/by/4.0/). 